2015

\title{
Heterotrophic and Autotrophic Contribution to Dinitrogen Fixation in the Gulf of Aqaba
}

Eyal Rahav

Barak Herut

Margaret R. Mulholland

Old Dominion University, mmulholl@odu.edu

Natalia Belkin

Hila Elifantz

See next page for additional authors

Follow this and additional works at: https://digitalcommons.odu.edu/oeas_fac_pubs

Part of the Biogeochemistry Commons, Ecology and Evolutionary Biology Commons, Microbiology Commons, and the Oceanography Commons

\section{Repository Citation}

Rahav, Eyal; Herut, Barak; Mulholland, Margaret R.; Belkin, Natalia; Elifantz, Hila; and Berman-Frank, Ilana, "Heterotrophic and Autotrophic Contribution to Dinitrogen Fixation in the Gulf of Aqaba" (2015). OEAS Faculty Publications. 241.

https://digitalcommons.odu.edu/oeas_fac_pubs/241

\section{Original Publication Citation}

Rahav, E., Herut, B., Mulholland, M.R., Belkin, N., Elifantz, H., \& Berman-Frank, I. (2015). Heterotrophic and autotrophic contribution to dinitrogen fixation in the Gulf of Aqaba. Marine Ecology Progress Series, 522, 67-77. doi: http://dx.doi.org/10.3354/ meps11143 


\section{Authors}

Eyal Rahav, Barak Herut, Margaret R. Mulholland, Natalia Belkin, Hila Elifantz, and Ilana Berman-Frank 


\title{
Heterotrophic and autotrophic contribution to dinitrogen fixation in the Gulf of Aqaba
}

\author{
Eyal Rahav ${ }^{1,2, *}$, Barak Herut ${ }^{2}$, Margaret R. Mulholland ${ }^{3}$, Natalia Belkin ${ }^{1}$, \\ Hila Elifantz ${ }^{1}$, Ilana Berman-Frank ${ }^{1}$ \\ ${ }^{1}$ Mina and Everard Goodman Faculty of Life Sciences, Bar-Ilan University, Ramat Gan 52900, Israel \\ ${ }^{2}$ Israel Oceanographic and Limnological Research, National Institute of Oceanography, Haifa 31080, Israel \\ ${ }^{3}$ Department of Ocean, Earth and Atmospheric Sciences, Old Dominion University, 4600 Elkhorn Avenue, Norfolk, \\ Virginia 23529-0276, USA
}

\begin{abstract}
We evaluated the seasonal contribution of heterotrophic and autotrophic diazotrophy to the total dinitrogen $\left(\mathrm{N}_{2}\right)$ fixation in the photic zone of a pelagic station in the northern Gulf of Aqaba, Red Sea. $\mathrm{N}_{2}$ fixation rates were highest during a Trichodesmium bloom in winter $(0.7 \mathrm{nmol}$ $\left.\mathrm{N} \mathrm{l}^{-1} \mathrm{~d}^{-1}\right)$, decreased 7-fold $1 \mathrm{wk}$ later throughout the upper $200 \mathrm{~m}\left(\sim 0.1 \mathrm{nmol} \mathrm{N} \mathrm{l}^{-1} \mathrm{~d}^{-1}\right)$, and were significantly coupled with both primary and bacterial productivity. $\mathrm{N}_{2}$ fixation rates were generally higher in the upper $200 \mathrm{~m}\left(\sim 0.4 \mathrm{nmol} \mathrm{N} \mathrm{l}^{-1} \mathrm{~d}^{-1}\right)$ during the thermally stratified summer and were correlated solely with bacterial productivity. Experimental enrichment of seawater by phosphorus (P) enhanced bacterial productivity and $\mathrm{N}_{2}$ fixation rates during both seasons by 3 - to 5 -fold. Moreover, during the stratified season, experimental amendments to seawater applying a combination of the photosynthetic inhibitor 3-(3,4-dichlorophenyl)-1,1-dimethylurea and a mixture of amino acids increased both bacterial productivity and $\mathrm{N}_{2}$ fixation rates. Our findings from the northern Gulf of Aqaba indicate that in the photic zone, a shift occurs in the diazotrophic community from phototrophic and heterotrophic populations in winter, including the cyanobacteria Trichodesmium, to predominantly heterotrophic diazotrophs in summer. These heterotrophic diazotrophs may be both carbon and P limited as illustrated by their response to additions of $\mathrm{P}$ and amino acids.
\end{abstract}

KEY WORDS: Autotrophic diazotrophs - Heterotrophic diazotrophs - Primary productivity · Bacterial productivity $\cdot \mathrm{N}_{2}$ fixation $\cdot$ Gulf of Aqaba $\cdot \mathrm{P}$ limitation

\section{INTRODUCTION}

The Gulf of Aqaba, located at the northern tip of the Red Sea, is surrounded by land on 3 sides and is characterized by a thermohaline circulation pattern caused by high evaporation rates $\left(1 \mathrm{~cm} \mathrm{~d}^{-1}\right.$; WolfVecht et al. 1992, Biton \& Gildor 2011). The gulf hydrology is characterized by a strong seasonal variability mainly due to deep winter mixing $(>300 \mathrm{~m}$; Labiosa \& Arrigo 2003) and strong summer stratification (Manasrah et al. 2007). Stratification enhances oligotrophy, with surface inorganic nutrient concentrations depleted during summer, and nitrogen $(\mathrm{N})$ and phosphorus (P) levels usually close to their detection limits (Fuller et al. 2005, Mackey et al. 2009, Meeder et al. 2012). During winter, deep vertical mixing advects inorganic nutrients from depth to the surface, with $\mathrm{P}$ and $\mathrm{N}$ reaching $\sim 0.1$ and $\sim 2 \mu \mathrm{M}$, respectively (Lindell \& Post 1995, Meeder et al. 2012).

The picophytoplankton $(<2 \mu \mathrm{m})$ predominate the phytoplankton populations in this system and are comprised mainly of Synechococcus, ProchlorococCus, and picoeukaryotes (Sommer 2000, Mackey et al. 2007, 2009, Iluz et al. 2009). The winter deep mixing as well as sporadic nutrient inputs during summer (e.g. Saharan dust events; Paytan et al. 2009) 
often induce blooms of larger phytoplankton such as diatoms (Lindell \& Post 1995, Mackey et al. 2007) and the diazotrophic (dinitrogen-fixing) cyanobacteria Trichodesmium spp. (Post et al. 2002).

Pelagic dinitrogen $\left(\mathrm{N}_{2}\right)$ fixation by diazotrophs is an important source of new bioavailable $\mathrm{N}$ in oligotrophic marine systems, converting $\mathrm{N}$ from the otherwise unavailable pool of atmospheric $\mathrm{N}_{2}$ to ammonia (Falkowski 1997). $\mathrm{N}_{2}$ fixation occurs in nitratedepleted surface photic layers of tropical oceans where diazotrophic phototrophs such as Trichodesmium spp. (Capone et al. 2005), unicellular cyanobacteria (Zehr \& Kudela 2001, Montoya et al. 2004), and non-photosynthetic diazotrophic bacterioplankton (Halm et al. 2012) are predominantly responsible for this process.

In the Gulf of Aqaba, several groups of diazotrophs have been identified based on their nucleic acid sequences, including the heterotrophic Alpha- and Gammaproteobacteria, as well as the autotrophic $T$. erythraeum and the unicellular cyanobacterial group A (Foster et al. 2009). Yet, detailed fixation rates are unavailable and the contribution of diazotrophs to new production in the Gulf of Aqaba is still unknown. A study examining the $\delta^{15} \mathrm{~N}$ signatures of zooplankton in the Gulf of Aqaba concluded that diazotrophs play only a minor role as a source of recently fixed new $\mathrm{N}$ to zooplankton nutrition in both winter and summer (Aberle et al. 2010). However, this claim was based on indirect interpretation of isotopic signatures from a higher trophic level. $\mathrm{N}_{2}$ fixation rates from the Gulf of Aqaba were measured directly in only 2 studies using the ${ }^{15} \mathrm{~N}_{2}$ assimilation technique (Foster et al. 2009, Rahav et al. 2013a), while another study measured species-specific rates (based on acetylene reduction) for concentrated Trichodesmium colonies using mesh plankton nets (Post et al. 2002). During the stratified summer (September), Foster et al. (2009) measured $\mathrm{N}_{2}$ fixation rates ranging from undetectable to a maximum of $1.2 \mathrm{nmol} \mathrm{N} \mathrm{l}^{-1} \mathrm{~d}^{-1}$. The highest rates measured by Foster et al. (2009) were during March (1.9 nmol N $\mathrm{l}^{-1} \mathrm{~d}^{-1}$ ), when the water column was mixed.

Nutrient availability, especially P and iron, regulates the distribution and abundance of diazotrophs, with high requirements for both (e.g. Raven 1988, Berman-Frank et al. 2001, Sañudo-Wilhelmy et al. 2001, Kustka et al. 2003). In the Gulf of Aqaba, large diazotrophs such as Trichodesmium can be limited by $\mathrm{P}$ while small cells with larger surface area to volume ratios were not as impacted (Mackey et al. 2007). Competition for nutrients is not limited to autotrophic phytoplankton but also occurs between phytoplankton and bacteria, especially in oligo- trophic systems, as demonstrated in the ultra-oligotrophic Levantine basin of the Mediterranean Sea (Thingstad et al. 2005). There, heterotrophic bacteria out-competed phytoplankton for $\mathrm{P}$ when additions were made to the ambient seawater and $\mathrm{P}$ cycling was shunted to the microbial loop (Thingstad et al. 2005). In a situation where $\mathrm{N}$ and $\mathrm{P}$ (or iron) are limiting, diazotrophs could have an advantage over phytoplankton that cannot access atmospheric $\mathrm{N}_{2}$. Moreover, heterotrophic diazotrophs, typically small cells $(<1 \mu \mathrm{m})$ with large surface area to volume ratios, may have a further competitive advantage over larger autotrophic diazotrophs such as Crocosphaera or the filamentous Trichodesmium. We therefore hypothesized that in the oligotrophic northern Gulf of Aqaba, heterotrophic diazotrophy may also have a competitive advantage over autotrophic diazotrophs and provide new bioavailable $\mathrm{N}$ for utilization by the marine food web. Our assumption was also based on the diversity of nitrogenase reductase (nifH) genes previously reported in the Gulf of Aqaba (Foster et al. 2009) which included heterotrophic diazotrophs and our recent study showing heterotrophs in both photic and aphotic water of the Gulf of Aqaba (Rahav et al. 2013a, O. Levitan et al. unpubl. data). Moreover, the abundance of cyanobacterial diazotrophs was also limited (Foster et al. 2009, O. Levitan et al. unpubl. data). The filamentous cyanobacterium Trichodesmium is found in very low numbers throughout the year and in 1996 increased in numbers averaging $\sim 100$ colonies $\mathrm{m}^{3}$ from March to August (Post et al. 2002). Small Trichodesmium blooms have been identified only sporadically (e.g. fall 1997, Post et al. 2002), and in the last few years usually after winter advection and mixing. Thus, in this study, we evaluated the contribution of heterotrophic and autotrophic diazotrophy to the total $\mathrm{N}_{2}$ fixation from a pelagic station in the northern Gulf of Aqaba in late winter while the water column was mixed and during summer stratification. We also examined the role of organic carbon $(\mathrm{C})$ and $\mathrm{P}$ availability in regulating heterotrophic diazotrophy by experimental nutrient enrichments.

\section{MATERIALS AND METHODS}

Water samples were collected from the RV 'Rotenberg' at Stn A $\left(29^{\circ} 28^{\prime} \mathrm{N}, 34^{\circ} 55^{\prime} \mathrm{E}\right)$ located at the northern tip of the Gulf of Aqaba during the mixed (March 2010) and during the stratified (September 2010, July 2012) periods. Previous observations of water profiles derived from 5 yr surveys (www.iui- 
eilat.ac.il/Research/NMPMeteoData.aspx) show that Stn A accurately characterizes the northern Red Sea waters (see Fig. S1 in the Supplement, available at www.int-res.com/articles/suppl/m522p067_supp.pdf). During March, 2 samplings were carried out. The first sampling took place $3 \mathrm{~d}$ after a flood event (flooding occurred on 3 March 2010, and sampling took place on 6 March 2010), and the second sampling 12 d later (18 March, see below for more details).

Samples were collected using 121 Niskin bottles mounted on a rosette equipped with a CTD (Seabird 19 Plus) and fluorometer (Turner designs, Cyclops7 for real-time chlorophyll a [chl a] fluorescence). Seawater for all analyses was dispensed into transparent 4.61 Nalgene incubation bottles. The filled Nalgene bottles were placed in transparent outdoor incubators with continuously flowing surface seawater to maintain ambient surface-water temperatures and irradiance. The incubators were shaded with neutral density screening to simulate in situ irradiance conditions obtained using a photosynthetically active radiation detector (Licor LI-1400).

\section{Inorganic nutrients}

Water samples were collected in $15 \mathrm{ml}$ acidwashed plastic scintillation vials and kept frozen until they were analyzed $\sim 1$ mo later. Nutrients were determined using a segmented flow Skalar SANplus System as described by Kress \& Herut (2001). The precision of nitrite + nitrate $\left(\mathrm{NO}_{2}+\mathrm{NO}_{3}\right)$, and phosphate $\left(\mathrm{PO}_{4}\right)$ measurements were $0.02 \mu \mathrm{M}$ and $0.003 \mu \mathrm{M}$, respectively. The limit of detection (2 times the standard deviation of the blank) was $0.075 \mu \mathrm{M}$ for $\mathrm{NO}_{2}+\mathrm{NO}_{3}$ and $0.008 \mu \mathrm{M}$ for $\mathrm{PO}_{4}$.

\section{Chl a extraction}

Duplicate seawater samples were filtered onto glass fiber filters ( $25 \mathrm{~mm}$ Whatman $\mathrm{GF} / \mathrm{F}$, ca. $0.7 \mu \mathrm{m}$ in pore size). The filters were stored at $-20^{\circ} \mathrm{C}$ in a dark box until analysis within 2 to $3 \mathrm{~d}$. Samples were extracted in $5 \mathrm{ml}$ of $90 \%$ acetone overnight at $4^{\circ} \mathrm{C}$ in the dark. $\mathrm{Chl}$ a concentrations were determined using a Turner Designs (TD-700) fluorometer with a $436 \mathrm{~nm}$ excitation filter and a $680 \mathrm{~nm}$ emission filter (Holm-Hansen et al. 1965). Blank filters were also stored in $90 \%$ acetone under the same conditions as those of the samples. Pure chl a (Sigma C6144- from Anacystis nidulans) was used to calibrate the measurements.

\section{Trichodesmium abundance}

Trichodesmium cell densities were determined after concentrating $10 \mathrm{l}$ of surface seawater from our study site and counting 3 subsamples. Trichodesmium cell number and size were estimated using a Sedgewick-Rafter Cell (S50) and a light microscope (Nikon Eclipse 80i equipped with DXM 1200F Nikon camera) using $40 \times$ magnification.

\section{$\mathbf{N}_{2}$ fixation rates}

$\mathrm{N}_{2}$ fixation rates were measured on field samples using the ${ }^{15} \mathrm{~N}_{2}$ assimilation technique described by Montoya et al. (1996) and Mulholland et al. (2006). Water was added to 4.61 polycarbonate Nalgene bottles that were sealed with septum tops and spiked with $9 \mathrm{ml}$ of ${ }^{15} \mathrm{~N}_{2}(98 \%)$. Bottles were incubated for $24 \mathrm{~h}$ under ambient surface seawater temperatures and covered with neutral density screening as described above. To terminate the incubations, water was filtered onto pre-combusted $25 \mathrm{~mm} \mathrm{GF/F} \mathrm{filters}$ $\left(450^{\circ} \mathrm{C}\right.$ for $\left.4 \mathrm{~h}\right)$, and filtered samples were analyzed on a Europa 20/20 mass spectrometer equipped with an automated $\mathrm{N}$ and $\mathrm{C}$ analyzer preparation module. $\mathrm{N}_{2}$ fixation was calculated according to Mulholland et al. (2006) using $\mathrm{N}$ solubility factors described by Weiss (1970). Most of our samplings were performed during 2010, prior to the implementation of the newly developed enriched seawater method (Mohr et al. 2010). A comparison between the traditional ${ }^{15} \mathrm{~N}_{2}$ injection (Montoya et al. 1996) and the modified enriched seawater method (Mohr et al. 2010) was conducted during the July 2012 sampling (Fig. S2 in the Supplement).

\section{Primary productivity}

Photosynthetic $\mathrm{C}$ fixation rates were estimated by determining the ${ }^{13} \mathrm{C}$ uptake rates (Mulholland \& Bernhardt 2005) from the same 4.61 polycarbonate Nalgene bottles in which ${ }^{15} \mathrm{~N}$ uptake was measured. Bottles were amended with highly enriched (99\%) $\mathrm{NaH}^{13} \mathrm{CO}_{3}$ (Sigma) to obtain $1 \%$ of the ambient dissolved inorganic C. Parallel dark bottles $(n=3)$ taken at each sampling depth were also incubated and subtracted from the light bottles of the same depth to correct for dark $\mathrm{C}$ fixation. Incubations were terminated by immediately filtering the entire contents of the incubation bottle onto pre-combusted $25 \mathrm{~mm} \mathrm{GF/F}$ filters $\left(450^{\circ} \mathrm{C}\right.$ for $\left.4 \mathrm{~h}\right)$. Filters were stored at $-20^{\circ} \mathrm{C}$ 
and then dried and pelleted in tin disks before their analysis using the Europa 20/20 mass spectrometer.

\section{Bacterial productivity rates}

Bacterial productivity was estimated using the $[4,5-$ ${ }^{3} \mathrm{H}$ ]-leucine (Amersham, specific activity: $160 \mathrm{Ci}$ $\mathrm{mmol}^{-1}$ ) incorporation method and normalized to $24 \mathrm{~h}$ (Simon et al. 1992). Briefly, 3 aliquots (1.7 ml each) from each sample were incubated with $100 \mathrm{nmol}^{-1}$ of $\left[4,5-{ }^{3} \mathrm{H}\right]$-leucine for $4 \mathrm{~h}$ at ambient room temperature in the dark. Preliminary experiments indicated that this was a saturating level of ${ }^{3} \mathrm{H}$-leucine and that incorporation was linear during this time (not shown). Triplicate seawater samples immediately amended with trichloroacetic acid (TCA) served as controls. The incubations were terminated with $100 \mu$ l of cold $\left(4^{\circ} \mathrm{C}\right)$ TCA $(100 \%)$ followed by the micro-centrifugation protocol (Smith \& Azam 1992). After adding $1 \mathrm{ml}$ of scintillation cocktail (Ultima-Gold) to each vial, the samples were counted using a TRI-CARB 2100 TR (Packard) liquid scintillation counter. We used a conversion factor of $3.1 \mathrm{~kg} \mathrm{C} \mathrm{mol}{ }^{-1}$ with an isotope dilution factor of 2.0 to calculate bacterial production (BP; Simon \& Azam 1989).

\section{Addition of $\mathbf{P}$}

Amendments of orthophosphate $\left(\mathrm{PO}_{4}{ }^{-3}\right)$ solution (Sigma) were added during early March (3 d after flood event) and September samplings into 4.61 polycarbonate Nalgene bottles when ${ }^{15} \mathrm{~N}_{2}$ was added, bringing the seawater to a final concentration of
$0.5 \mu \mathrm{M} \mathrm{PO}_{4}{ }^{-3}$. The incubation times were identical to that of the un-amended controls, and incubations were terminated under the same conditions (see above).

\section{Addition of 3-(3,4-dichlorophenyl)-1,1- dimethylurea (DCMU) and amino acid mixture}

The photosynthetic inhibitor DCMU, dissolved in dimethyl sulfoxide, was added to a final concentration of $50 \mu \mathrm{M}$, which is the effective minimal concentration required for photosynthetic inhibition (Clavier \& Boucher 1992), in 4.61 polycarbonate Nalgene bottles along with ${ }^{15} \mathrm{~N}_{2}$. Furthermore, a mixture of 20 amino acids (Sigma A9906) was added, bringing the seawater to a final concentration of $500 \mathrm{nM}$ of dissolved organic C (DOC). We hypothesized that the combination of DCMU and amino acids would promote heterotrophy over autotrophy by supplying DOC and dissolved inorganic $\mathrm{N}$ sources from the amino acids while suppressing photosynthesis, as DCMU blocks the linear electron flow from PSII to the plastoquinone.

\section{RESULTS}

\section{Seasonal changes of productivity in the water column}

The upper mixed layer of the study site differed between September 2010 and July 2012 (summer) and March 2010 (winter) (Fig. 1A). In March, the upper $200 \mathrm{~m}$ was mixed, whereas the water column
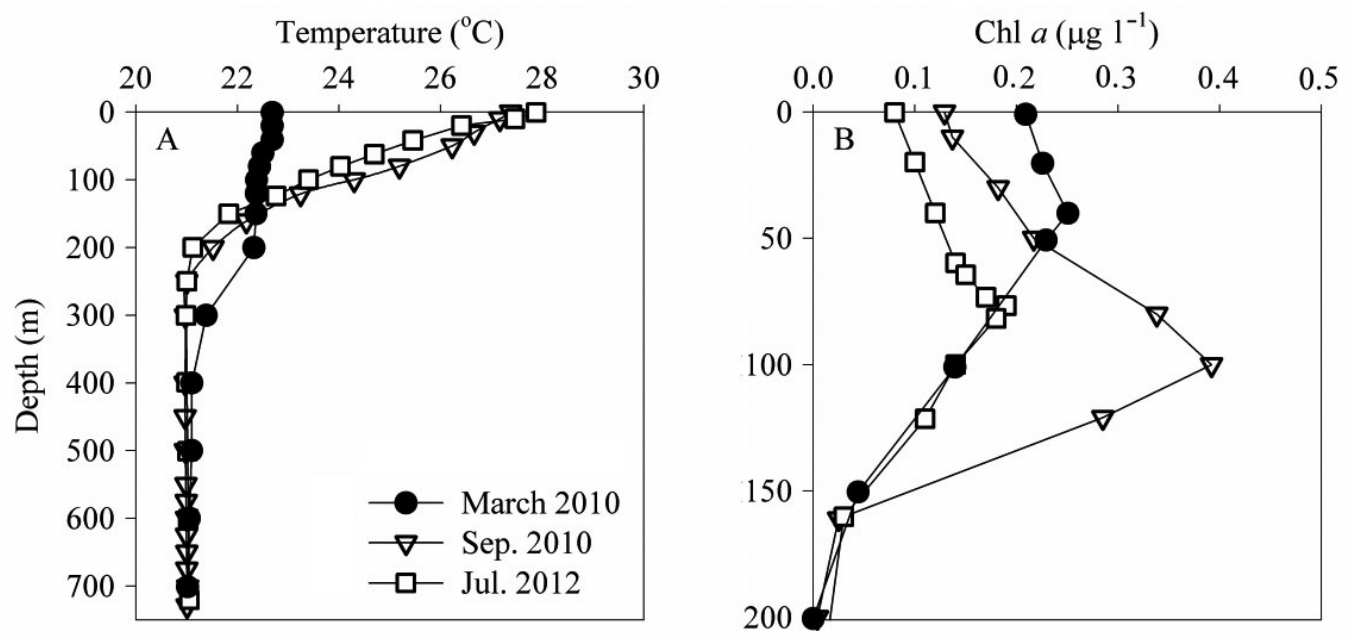

Fig. 1. Depth profiles of (A) temperature and (B) chlorophyll (chl a) during the mixed (March 2010) and the stratified (September 2010 and July 2012) periods. Note the different $y$-axis scales 

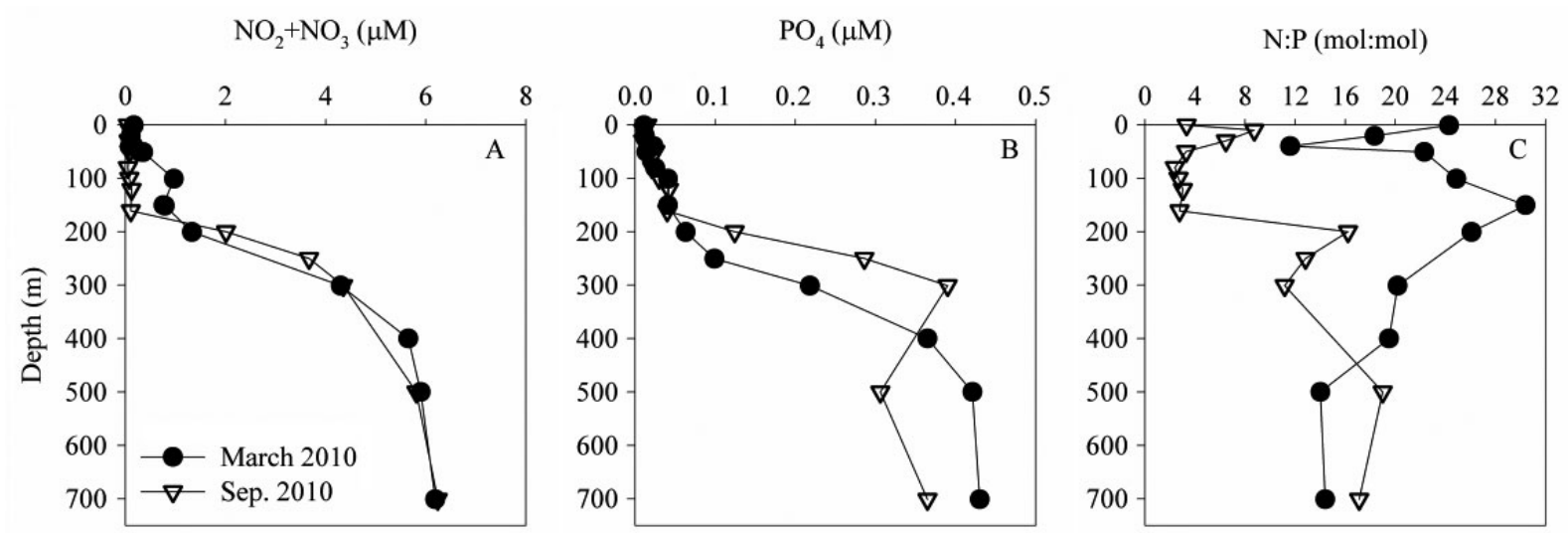

Fig. 2. Depth profiles of (A) nitrate + nitrite, (B) orthophosphate, and (C) N:P (mol:mol) ratio during the mixed (March 2010) and stratified (September 2010) periods. Data from July 2012 are unavailable

was much warmer during summer (July and September) and exhibited full stratification in July (Fig. 1A). The average sea surface temperature was $23^{\circ} \mathrm{C}$ in March and 27 to $28^{\circ} \mathrm{C}$ in July and September. At a depth of $400 \mathrm{~m}$, no seasonal temperature effect was observed, and the seawater temperature remained at $\sim 21^{\circ} \mathrm{C}$ (Fig. 1A).

During our samplings, the highest surface (5-20 m) chl a concentration was detected during the winter sampling, with $0.19 \mu \mathrm{g} \mathrm{l}^{-1}$ relative to a concentration of $0.14 \mathrm{~g} \mathrm{l}^{-1}$ during stratification (Fig. 1B). The deep chlorophyll maximum (DCM) differed between periods, with the shallowest DCM $(\sim 50 \mathrm{~m})$ recorded during March, increasing to $80 \mathrm{~m}$ in mid-July, and reaching $100 \mathrm{~m}$ at the end of the summer (September). The chl a concentration of the DCM in March was $0.25 \mu \mathrm{g} \mathrm{l}^{-1}$, while during summer it varied from $0.19 \mu \mathrm{g} \mathrm{l}^{-1}$ in June to $0.33 \mu \mathrm{g} \mathrm{l^{-1 }}$ in September (Fig. 1B).

Inorganic nutrient concentrations in the upper $50 \mathrm{~m}$ were low in March, averaging $\sim 0.15 \mu \mathrm{M}$ and $0.01 \mu \mathrm{M}$ for $\mathrm{NO}_{2}+\mathrm{NO}_{3}$ and $\mathrm{PO}_{4}$, respectively (Fig. 2A,B). During summer, $\mathrm{NO}_{2}+\mathrm{NO}_{3}$ were slightly above the detection limit in the upper $160 \mathrm{~m}$ $(0.1 \mu \mathrm{M})$, whereas $\mathrm{PO}_{4}$ was were negligible in the upper $50 \mathrm{~m}(0.01 \mu \mathrm{M}$; Fig. 2A,B). The maximal nutrient concentrations were found below $200 \mathrm{~m}$ at all samplings (Fig. 2A,B). During March, the N:P ratio (mol:mol) was higher $(\sim 20: 1)$ than the conventional 16:1 Redfield ratio (Redfield et al.

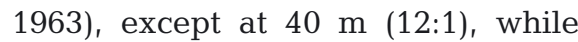
during summer, the $\mathrm{N}: \mathrm{P}$ was lower than $16: 1$ in the upper $200 \mathrm{~m}(\sim 2$ to $8: 1$; Fig. 2C).
$\mathrm{BP}$ rates were uniformly low throughout the upper $200 \mathrm{~m}$ in March $\left(0.2-0.8 \mu \mathrm{g} \mathrm{Cl}^{-1} \mathrm{~d}^{-1}\right)$, whereas higher BP rates were usually obtained during July and Sep-

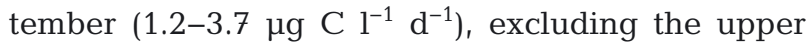
$10 \mathrm{~m}$ in July 2012 (Table 1 ). Surface primary productivity (PP) ranged from 2.4 to $3.1 \mu \mathrm{g} \mathrm{C} \mathrm{l}^{-1} \mathrm{~d}^{-1}$ in March, whereas during the summer months PP was lower, ranging from 0.3 to $0.6 \mu \mathrm{g} \mathrm{Cl}^{-1} \mathrm{~d}^{-1}$ (Table 1). PP declined with depth during both the mixed and stratified periods, with non-detectable rates at $100 \mathrm{~m}$ and $200 \mathrm{~m}$, respectively, where $<0.1 \%$ of surface irradiance was measured (Table 1).

The BP:PP ratio provides a measure of the metabolic status of the environment, i.e. whether the environment is predominantly heterotrophic or autotrophic (Lagaria et al. 2010, Rahav et al. 2013b). A ratio $<1$ indicates higher autotrophic fixation of $\mathrm{C}$ relative to heterotrophic $\mathrm{C}$ fixation, and, conversely, when this ratio is $>1$, higher heterotrophic to autotrophic production. In this study, the BP:PP ratio in March was generally $<1$, except for depths below the

Table 1. Bacterial and primary productivity rates (BP and $\mathrm{PP}$, respectively) measured at different sampling periods. The values noted are the range, and the number of repetitions (n) is stated in parentheses. DCM: deep chlorophyll maximum

\begin{tabular}{|c|c|c|c|}
\hline Sampling depth & $\begin{array}{l}\text { March } 2010 \\
\text { (Mixed period) }\end{array}$ & $\begin{array}{c}\text { July } 2012 \\
\text { (Stratified period) }\end{array}$ & $\begin{array}{l}\text { September } 2010 \\
\text { (Stratified period) }\end{array}$ \\
\hline \multicolumn{4}{|l|}{$B P\left(\mu g C 1^{-1} d^{-1}\right)$} \\
\hline Surface to DCM & $0.7-0.8(6)$ & $0.3(3)$ & $1.9-3.7(12)$ \\
\hline DCM & $0.3-0.4(6)$ & $1.2-1.8(3)$ & $2.3-2.9(3)$ \\
\hline Below DCM & $0.2-0.4(6)$ & $2.2-2.3(3)$ & $1.5-2.3(6)$ \\
\hline \multicolumn{4}{|l|}{$P P\left(\mu g C l^{-1} d^{-1}\right)$} \\
\hline Surface to DCM & $2.4-3.1(6)$ & $0.6(3)$ & $0.3-0.6(6)$ \\
\hline DCM & $0.7-1.3(3)$ & $0.2(3)$ & $0.4(3)$ \\
\hline Below DCM & 0-0.4 (9) & $0(3)$ & $0-0.4(6)$ \\
\hline
\end{tabular}




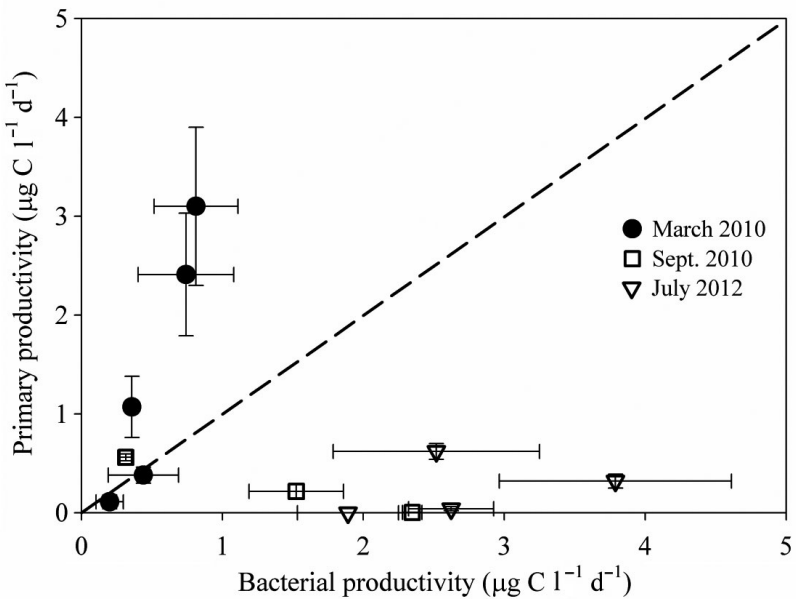

Fig. 3. Relationship between primary productivity versus bacterial productivity from all depths and samplings. The solid line represents a ratio of 1 between the variables, where $\mathrm{C}$ is fixed by bacterial and primary productivity equally

DCM, where it approximated 1 (Table 1). In both July 2012 and September 2010, the BP:PP ratio was always $>1$ (Table 1, Fig. 3 ).

$\mathrm{N}_{2}$ fixation rates were uniformly low within the upper $150 \mathrm{~m}$ in March $\left(\sim 0.1 \mathrm{nmol} \mathrm{N} \mathrm{l}^{-1} \mathrm{~d}^{-1}\right)$, while in the aphotic zone $(>200 \mathrm{~m})$ higher $\mathrm{N}_{2}$ fixation rates were recorded (0.2 nmol N ${ }^{-1} \mathrm{~d}^{-1}$, Fig. 4). During summer stratification, surface $\mathrm{N}_{2}$ fixation rates were $\sim 0.4 \mathrm{nmol} \mathrm{N} \mathrm{l}^{-1} \mathrm{~d}^{-1}$ in July, and increased to a maximum of $0.5 \mathrm{nmol} \mathrm{N} \mathrm{l}^{-1} \mathrm{~d}^{-1}$ at $100 \mathrm{~m}$ depth in September (Fig. 4).

The measured rates of $\mathrm{N}_{2}$ fixation were examined with the corresponding heterotrophic metabolism

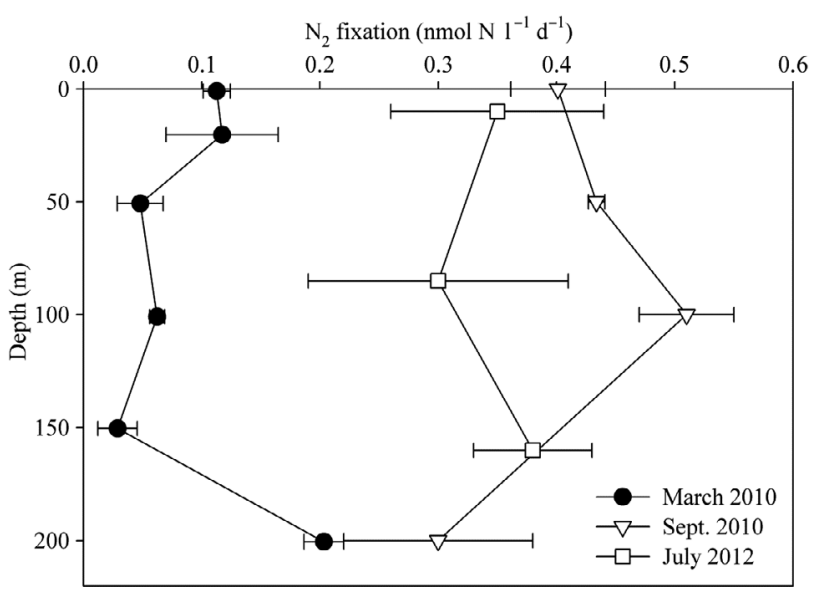

Fig. 4. Depth profiles of dinitrogen $\left(\mathrm{N}_{2}\right)$ fixation during the mixed (March 2010) and stratified periods (September 2010 and July 2012)

(BP) and phototrophic C fixation (PP) (Fig. 5). BP correlated significantly and positively with $\mathrm{N}_{2}$ fixation for both the winter $\left(R^{2}=0.98, p=0.003, n=15\right)$ and summer samplings $\left(\mathrm{R}^{2}=0.52, \mathrm{p}=0.01, \mathrm{n}=21\right.$; Fig. 5A). No correlation with PP was apparent for either the July or the September samplings (Fig. 5A). In March, $\mathrm{PP}$ and $\mathrm{N}_{2}$ fixation were positively $\left(\mathrm{R}^{2}=\right.$ $0.84, \mathrm{n}=15)$, though not significantly, correlated $(\mathrm{p}=$ 0.07; Fig. 5B).

\section{Addition of phosphorus}

The response of productivity (bacterial and primary) and diazotrophy to amendment of $\mathrm{PO}_{4}(\mathrm{P})$ was tested on surface $(10 \mathrm{~m})$ seawater in March while rel-
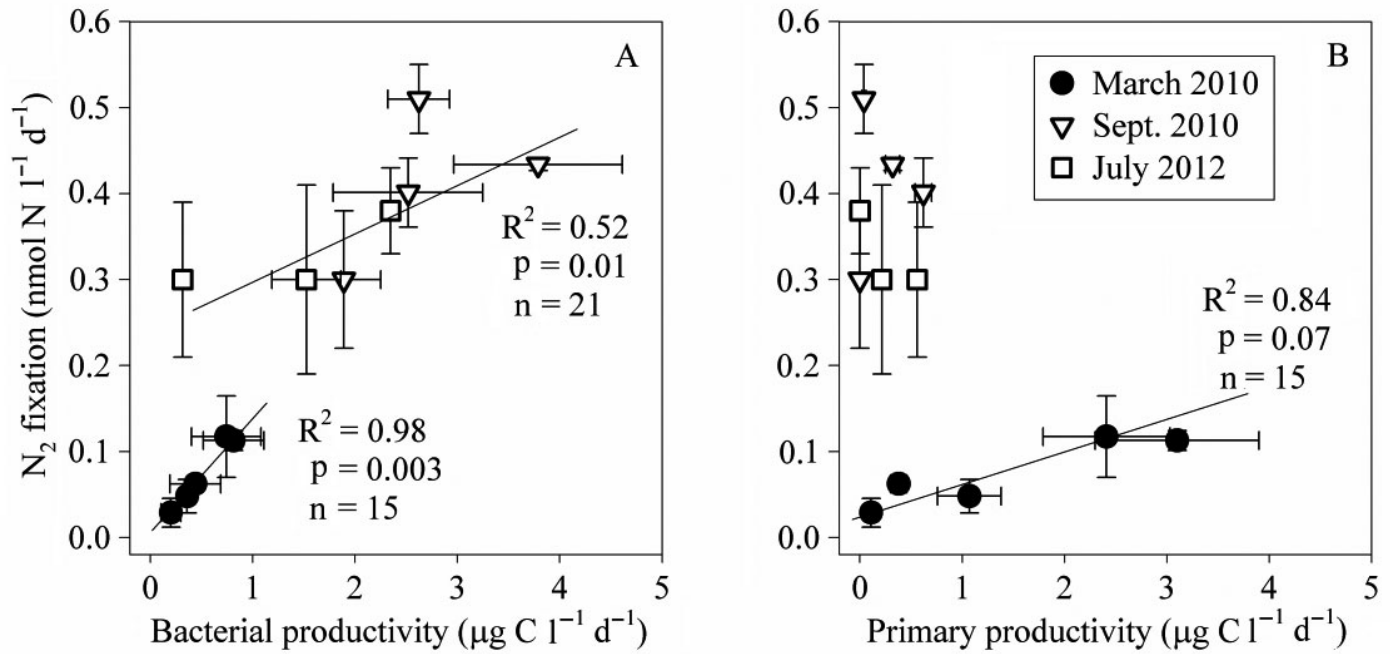

Fig. 5. Relationship between dinitrogen $\left(\mathrm{N}_{2}\right)$ fixation and $(\mathrm{A})$ bacterial productivity and (B) primary productivity during the mixed (March 2010) and stratified periods (September 2010 and July 2012). The correlation coefficients are given in the graphs 

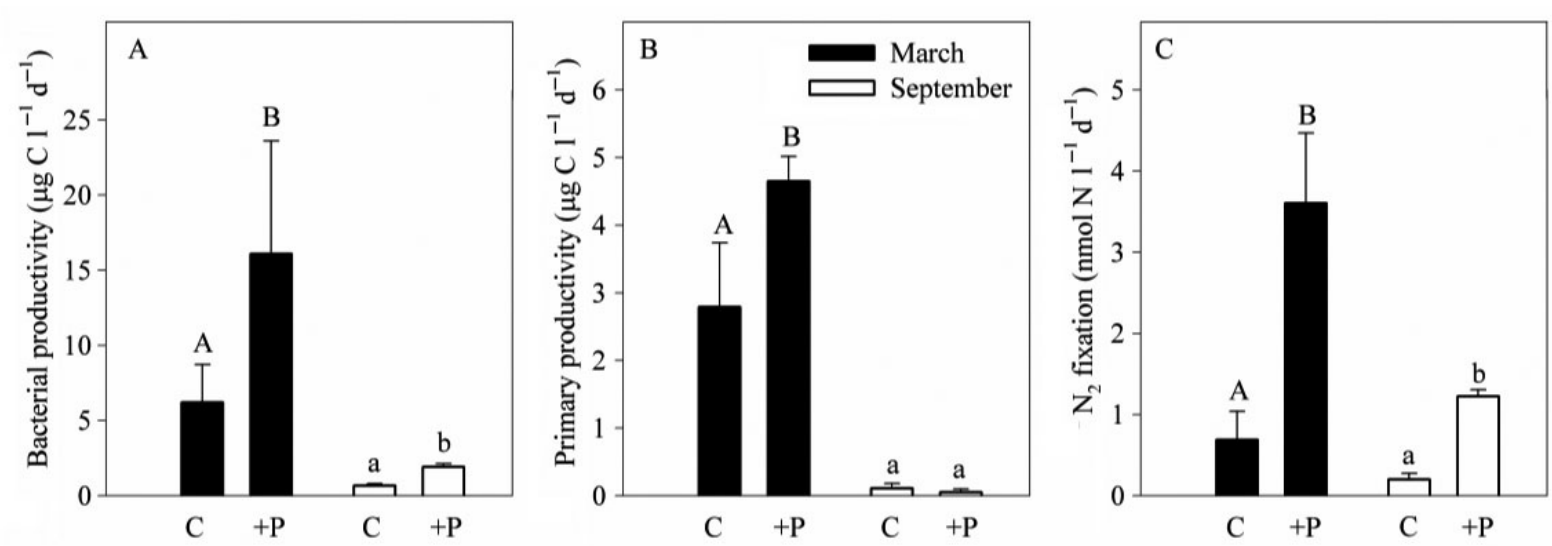

Fig. 6. Effect of phosphorus (P) addition on (A) bacterial productivity, $(\mathrm{B})$ primary productivity, and $(\mathrm{C})$ dinitrogen $\left(\mathrm{N}_{2}\right)$ fixation during the mixed (black bars) and stratified periods (white bars). Values are means + SD from 3 independent replicates performed for each control and treatment. The letters above the columns represent statistically significant differences (ANOVA, $\mathrm{p}<0.05$ ) between mean values for $\mathrm{P}$ addition $(+\mathrm{P})$ versus unamended controls $\left(\mathrm{C}_{\text {; }}\right.$ no addition)

atively high Trichodesmium abundances were observed $\left(2.3 \pm 2.0 \times 10^{3}\right.$ trichomes $\mathrm{m}^{-3}, \sim 1 \mathrm{wk}$ prior to the detailed depth sampling described here) and again in September when Trichodesmium abundance was $<0.1 \times 10^{3}$ trichomes $\mathrm{m}^{-3}$. The initial BP rates were high in March compared with the September sampling (6.0 and $0.70 \mu \mathrm{g} \mathrm{C} \mathrm{l}^{-1} \mathrm{~d}^{-1}$, respectively; Fig. 6A). During both seasons, a positive significant increase was observed after the addition of $\mathrm{P}$ with $\sim 3$-fold higher rates in P-amended samples compared with the seawater controls $(>16$ and $1.9 \mu \mathrm{g}$ $\mathrm{C}^{-1} \mathrm{~d}^{-1}$ for March and September respectively, Fig. 6A). Moreover, in March, the PP rates increased significantly in response to the addition of $\mathrm{P}$ (from 2.8 to $4.7 \mu \mathrm{g} \mathrm{C}^{-1} \mathrm{~d}^{-1}$; Fig. $6 \mathrm{~B}$ ), while in September the initial PP rates were much lower $\left(\sim 0.1 \mu \mathrm{g} \mathrm{C} \mathrm{l}^{-1} \mathrm{~d}^{-1}\right)$, and there was no significant change $24 \mathrm{~h}$ after $\mathrm{P}$ amendment (Fig. 6B). $\mathrm{N}_{2}$ fixation rates were significantly enhanced by additions of $\mathrm{P}$ (ANOVA, p < 0.05 ), with 5-fold higher rates measured in March (3.6 nmol N ${ }^{-1} \mathrm{~d}^{-1}$,) and 3-fold higher rates obtained in September (1.2 $\mathrm{nmol} \mathrm{N}^{-1} \mathrm{~d}^{-1}$; Fig. 6C).

\section{Photoautotrophic versus heterotrophic diazotrophy during July 2012}

To examine the physiological contribution of photoautotrophic and heterotrophic diazotrophs during the summer stratification, while fixed $\mathrm{N}$ concentrations $\left(\mathrm{NO}_{3}+\mathrm{NO}_{2}\right)$ are close to their analytical detection limits (Fig. 2A), we experimentally manipulated the system by the combined addition of the photosynthetic inhibitor DCMU and a mixture of 20 amino acids to water collected from 3 depths within the photic layer $\left(10,85\right.$, and $160 \mathrm{~m}_{i}$ Table $\mathrm{S} 1$ in the
Supplement). The additions resulted in 2- to 8-fold higher rates of BP at all depths sampled (Fig. 7A), whereas the PP rates were reduced by 70 to $80 \%$ compared with those of the control treatments (i.e. without any addition; Fig. 7B). The additions also stimulated $\mathrm{N}_{2}$ fixation rates with a 2- to 4 -fold increase in rates at all depths (Fig. $7 \mathrm{C}$ ). The maximal enhancement of $\mathrm{N}_{2}$ fixation rates was observed in water from the DCM $(85 \mathrm{~m})$, in which $\mathrm{N}_{2}$ fixation rates increased from 0.3 to $1.2 \mathrm{nmol} \mathrm{N} \mathrm{l^{-1 }} \mathrm{d}^{-1}$ (Fig. 7C).

\section{DISCUSSION}

Our results highlight the complexity and variability of $\mathrm{N}_{2}$ fixation in the Gulf of Aqaba with seasonally differential contributions of heterotrophic and autotrophic diazotrophs. The additions of new $\mathrm{N}$ via diazotrophy could enhance production in the nutrient-depleted surface waters of the oligotrophic Gulf of Aqaba, especially during the long stratified period (April to November annually). This process may be especially important, as the Gulf of Aqaba lacks other significant external inputs of $\mathrm{N}$ via rivers or high precipitation. Diazotrophs also require $\mathrm{P}$ for the energetically demanding process of $\mathrm{N}_{2}$ fixation, with $P$ availability placing further controls on $\mathrm{N}_{2}$ fixation rates in many marine environments ( $\mathrm{Sohm}$ et al. 2011, Moore et al. 2013). The oligotrophic Gulf of Aqaba is considered P-limiting for PP during a significant part of the year (Chen et al. 2007). This limitation can be observed by the greater than Redfield (16:1) N:P ratios in the Gulf of Aqaba under 'typical' conditions (i.e. no flood or other inputs; Fig. $2 \mathrm{C}$ and Meeder et al. 2012), in the BP:PP ratio >1 during the 

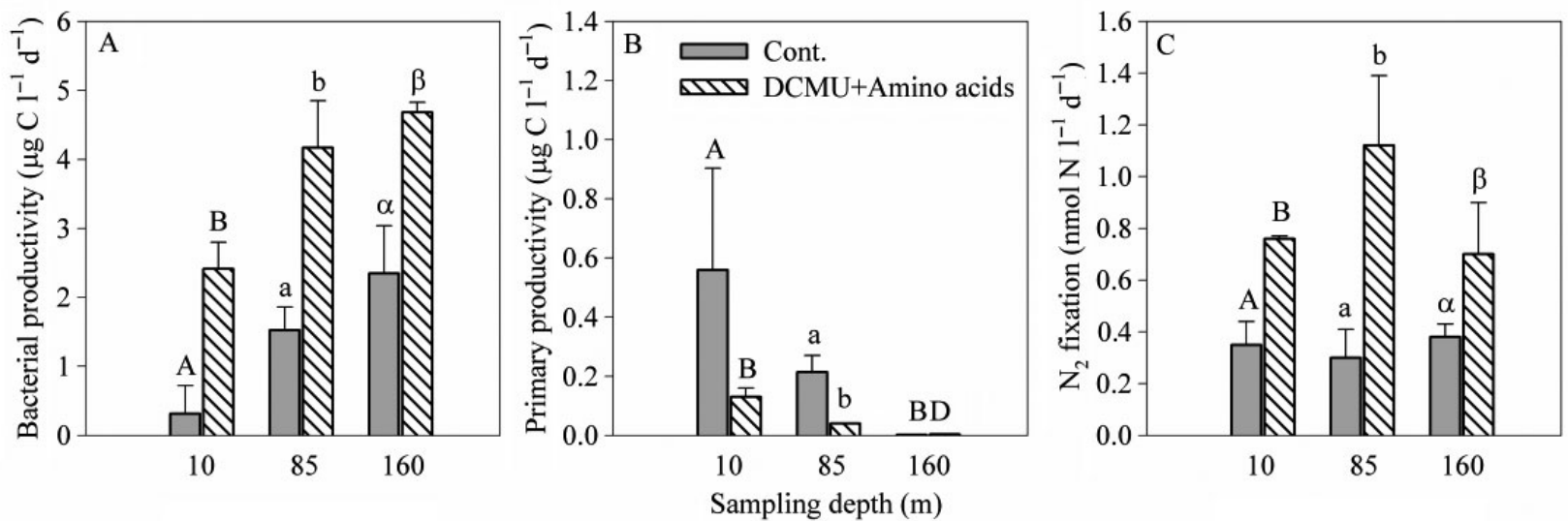

Fig. 7. Effect of 3-(3,4-dichlorophenyl)-1,1-dimethylurea (DCMU) and a mixture of amino acids on (A) bacterial productivity, (B) primary productivity, and (C) dinitrogen $\left(\mathrm{N}_{2}\right)$ fixation during the stratified summer period (July 2012). Values are means $+\mathrm{SD}$ from 3 independent replicates performed for each control and treatment. The letters above the columns represent statistically significant differences (ANOVA, $\mathrm{p}<0.05$ ) between mean values for DCMU + amino acid additions and control treatments between depths. For more details, see 'Materials and methods'. BD: below detection

July and September samplings (Fig. 3 and Table 1) indicating a heterotrophic rather than autotrophic metabolic dominance, and in the increased alkaline phosphatase levels of some groups of phytoplankton induced by limited P availability (Mackey et al. 2007) under stratified conditions.

Yet, when seawater samples from different stations in the northern Gulf of Aqaba were amended with $\mathrm{PO}_{4}(0.4 \mu \mathrm{M})$ in $2006, \mathrm{~N}_{2}$ fixation rates were not stimulated (Foster et al. 2009). In contrast, our experimental $\mathrm{PO}_{4}$ amendments $(0.5 \mu \mathrm{M})$ significantly enhanced $\mathrm{N}_{2}$ fixation rates both in early March, when large Trichodesmium colonies were counted (see below), and in September (Fig. 6). This response corresponds to findings showing that larger phytoplankton (including Trichodesmium) were P-limited in the Gulf of Aqaba, whereas smaller phytoplankton (picophytoplankton) were not (Mackey et al. 2007).

Natural alleviation of $\mathrm{P}$ limitation was recorded after the flood at the beginning of March (www.ims. gov.il). Flooding enriched $\mathrm{NO}_{2}+\mathrm{NO}_{3}$ and $\mathrm{PO}_{4}$ concentrations in surface waters and produced a subsequent increase in Trichodesmium abundance and corresponding high rates of PP (Fig. 6B) and $\mathrm{N}_{2}$ fixation (Fig. 6C). With the decline in available $\mathrm{P} 1 \mathrm{wk}$ after the flood $\left(50 \%\right.$ reduction in $\mathrm{PO}_{4}$ concentrations), Trichodesmium numbers substantially declined ( $>90 \%$ ), resulting in lower $\mathrm{N}_{2}$ fixation and PP rates (Fig. 4, Table 1).

As in any natural environment, spatial and temporal variability exists in community composition and diversity as well as in the resulting metabolic processes. Thus, while the ambient $\mathrm{P}$ concentrations $(<0.05 \mu \mathrm{M})$ were similar in both our study and that of Foster et al. (2009), the response of the community to enhanced $\mathrm{P}$ concentrations differed between the studies, illustrating the natural variability of community responses to $\mathrm{P}$ limitation (see also Mackey et al. 2007) and highlighting the necessity of spatial and temporal sampling approaches to determine both composition and metabolic function.

The differential responses to $\mathrm{P}$ availability and limitation may also result from the altered composition of diazotrophs and the ensuing structure of the diazotrophic community. Marine diazotrophy was traditionally linked to autotrophic metabolism and primary productivity attributed to a predominance of cyanobacterial diazotrophs in the photic surface layers (Capone et al. 1997, Gruber, 2008). Newer research has demonstrated increased diversity of diazotrophs (Zehr \& Kudela 2011). Our findings show that in the Gulf of Aqaba, the close coupling between autotrophs and diazotrophs is only found during the mixed period and when cyanobacteria such as Trichodesmium are abundant in the gulf waters (Fig. 5). Thus, Trichodesmium responded to the flood-derived nutrient inputs in March, and $\mathrm{N}_{2}$ fixation rates increased in parallel with higher BP and PP rates; these were all enhanced further upon addition of $\mathrm{P}$ (Table S1, Fig. 6A,B). Yet, we cannot rule out that the correlation of $\mathrm{N}_{2}$ fixation with both BP and PP during March can also imply that only 1 of these variables (PP or BP) was indeed coupled with $\mathrm{N}_{2}$ fixation while the other was indirectly related. For example, it is possible that in March only PP was coupled with $\mathrm{N}_{2}$ fixation, while the increase in BP was related to the enhanced PP and not to diazotrophy per se.

During times of stratification, however, $\mathrm{N}_{2}$ fixation rates were uncoupled from $\mathrm{PP}$, and addition of external $\mathrm{P}$ enhanced only BP (Fig. 6A) and $\mathrm{N}_{2}$ fixation 
(Fig. 6C). We assume that the increase in BP and decline in PP in September was caused by heterotrophic bacteria bypassing and outcompeting primary producers for the inorganic $\mathrm{P}$ as was previously shown during the CYCLOPS campaign in the eastern Mediterranean Sea (Thingstad et al. 2005). Moreover, the diazotrophic heterotrophic fraction could utilize this resource and increase $\mathrm{N}_{2}$ fixation rates, explaining the positive correlation between $\mathrm{BP}$ and $\mathrm{N}_{2}$ fixation and the uncoupling between $\mathrm{N}_{2}$ fixation and PP (Fig. 5).

Although BP is not diazotroph specific and represents the uptake of a large part of the bacterial community (Sebastián \& Gasol 2013), the positive correlation obtained in all sampling periods between $\mathrm{N}_{2}$ fixation and BP suggests that heterotrophic bacteria were also fixing $\mathrm{N}_{2}$ (Fig. 5; Rahav et al. 2013a). Moreover, to further understand the contribution of heterotrophy to $\mathrm{N}_{2}$ fixation during summer, we experimentally provided heterotrophs with a competitive advantage over autotrophs (not only diazotrophs). Our main objective was to inhibit photosynthesis (using DCMU and darkness; see 'Materials and methods') of autotrophic diazotrophs requiring photosynthetically derived energy for $\mathrm{N}_{2}$ fixation (Postgate 1998). Simultaneously, we stimulated the heterotrophic community by addition of an amino acid mixture that supplies high concentrations of dissolved and particulate organic $\mathrm{C}$ and $\mathrm{N}$. The additions resulted in a dramatic decline in PP rates by $\sim 80 \%$ at all depths sampled (photic depth; 0-160 m), whereas both BP and $\mathrm{N}_{2}$ fixation rates were substantially increased (Fig. 7, Table S1). While the elevated concentrations of $\mathrm{N}$ sources delivered by the addition of amino acids can theoretically depress $\mathrm{N}_{2}$ fixation rates, Knapp (2012) showed that $\mathrm{N}_{2}$ fixation can continue at substantial rates in the presence of as much as $30 \mu \mathrm{M} \mathrm{NO}_{3}$ and/or $200 \mu \mathrm{M} \mathrm{NH}_{4}{ }^{+}$. Thus, the amino acid responses further highlight the important role that heterotrophic diazotrophs could play in the Gulf of Aqaba, at least during summer.

Whether contributed via autotrophic or heterotrophic diazotrophs, the total rates of $\mathrm{N}_{2}$ fixation in the photic layer of Stn A correspond with previous measurements from the Gulf of Aqaba. The mean $\mathrm{N}_{2}$ fixation rates measured throughout the entire water column during the summer months (July and September) were 2- to 3-fold higher than the rates obtained in March and were similar to reported rates from the Gulf of Aqaba ( 0.01 to $0.8 \mathrm{nmol} \mathrm{N} \mathrm{l}^{-1} \mathrm{~d}^{-1}$, Foster et al. 2009, Rahav et al. 2013a) as well as other oligotrophic areas (Mague et al. 1974, Capone et al. 1997, Karl et al. 2002, White et al. 2007, Rahav et al.
$2013 b, c)$. The high variability in $\mathrm{N}_{2}$ fixation rates during March reported by Foster et al. (2009) may imply that they also measured rates under both Trichodesmium 'bloom' and 'non-bloom' scenarios or they could reflect inter-annual changes.

The generally low rates of $\mathrm{N}_{2}$ fixation measured in this system may underestimate actual rates. Our $\mathrm{N}_{2}$ fixation measurements were carried out mostly during 2010, prior to the publication of the newly modified methodology for measuring $\mathrm{N}_{2}$ fixation rates (Mohr et al. 2010) that involves the addition of enriched $\left({ }^{15} \mathrm{~N}_{2}\right)$ seawater rather than adding ${ }^{15} \mathrm{~N}_{2}$ as gas bubbles (i.e. Montoya et al. 1996). The gas bubble enrichment method may underestimate $\mathrm{N}_{2}$ fixation rates by a factor of 2 or more in some circumstances (Großkopf et al. 2012, Wilson et al. 2012, Rahav et al. 2013c), yet in long incubations (24 h), the underestimation of $\mathrm{N}_{2}$ fixation using the bubble method is reduced, as the gas bubbles should have equilibrated within the first several hours of the incubation (Mohr et al. 2010, Mulholland et al. 2012). Moreover, comparison between the 2 methods in July 2012 (surface waters, $\mathrm{n}=8$ ) yielded an insignificant (1-way ANOVA, p > 0.05) 1.4- to 1.9-fold increase in rates using the enriched seawater method (Fig. S2). Currently, it is impossible to convert between the methods. Yet, even if we assume a $50 \%$ underestimation of $\mathrm{N}_{2}$ fixation rates, we still observe temporal differences in $\mathrm{N}_{2}$ fixation rates between the studied periods, suggesting that methodological differences alone cannot account for the observed seasonal changes.

Due to the lack of studies on $\mathrm{N}_{2}$ fixation in the Gulf of Aqaba, it is currently impossible to discuss interannual differences and obtain any patterns for longer timescales. Studying this biologically important process in this system, including its aphotic layers (Bonnet et al. 2013, Rahav et al. 2013a), at finer spatial and temporal resolution may provide important data on biogeochemical cycling of $\mathrm{N}$ and $\mathrm{C}$ in the Gulf of Aqaba and thus might help clarify the interactions and contributions of diazotrophy to the marine food web. Recent data demonstrating expanded niches and roles of heterotrophic diazotrophy globally suggest that $\mathrm{N}_{2}$ fixation may be severely underestimated in the global budget (Fernandez et al. 2011, Hamersley et al. 2011, Bonnet et al. 2013, Farnelid et al. 2013, Rahav et al. 2013a, Bentzon-Tilia et al. 2014). Subsequent efforts should be undertaken in this field to understand the scope of interactions between heterotrophic and autotrophic diazotrophs. Moreover, according to climate change predictions, the surface oceans in the future will be characterized by a more 
stable thermal stratification and exacerbated limitation of inorganic nutrients for primary production. These conditions may provide heterotrophic diazotrophs with a competitive advantage over autotrophic diazotrophs, which could impact community composition and structure as well as the functioning of the biological pump.

Acknowledgements. This work was supported by the Israel Science Foundation grants (996/08) to I.B.F. and B.H. and by the German Ministry of Education and Research (BMBF) grant 03F0640A to I.B.F. Our thanks to the captain and crews of the RV 'Rotenberg'. This study is in partial fulfillment of E.R.'s PhD thesis for Bar Ilan University.

\section{LITERATURE CITED}

Aberle N, Hansen T, Boettger-Schnack R, Burmeister A, Post AF, Sommer U (2010) Differential routing of 'new' nitrogen toward higher trophic levels within the marine food web of the Gulf of Aqaba, Northern Red Sea. Mar Biol 157:157-169

Bentzon-Tilia M, Traving SJ, Mantikci M, Knudsen-Leerbeck H, Hansen JLS, Markager S, Riemann L (2014) Significant $\mathrm{N}_{2}$ fixation by heterotrophs, photoheterotrophs and heterocystous cyanobacteria in two temperate estuaries. ISME J 9:273-285

> Berman-Frank I, Cullen JT, Shaked Y, Sherrell RM, Falkowski PG (2001) Iron availability, cellular iron quotas, and nitrogen fixation in Trichodesmium. Limnol Oceanogr 46:1249-1260

> Biton E, Gildor H (2011) The general circulation of the Gulf of Aqaba (Gulf of Eilat) revisited: the interplay between the exchange flow through the Straits of Tiran and surface fluxes. J Geophys Res 116:C08020, doi:10.1029/ 2010JC006860

> Bonnet S, Dekaezemacker J, Turk-Kubo KA, Moutin T and others (2013) Aphotic $\mathrm{N}_{2}$ fixation in the Eastern Tropical South Pacific Ocean. PLoS ONE 8:e81265

> Capone DG, Zehr JP, Paerl HW, Bergman B (1997) Trichodesmium, a globally significant marine cyanobacterium. Science 276:1221-1229

> Capone DG, Burns JA, Montoya JP, Subramanian A and others (2005) Nitrogen fixation by Trichodesmium spp.: an important source of new nitrogen to the tropical and subtropical North Atlantic Ocean. Global Biogeochem Cycles 19:GB2024, doi:10.1029/2004GB002331

> Chen Y, Mills S, Street J, Golan D, Post A, Jacobson M, Pay$\tan A$ (2007) Estimates of atmospheric dry deposition and associated input of nutrients to Gulf of Aqaba seawater. J Geophys Res 112:D04309, doi:10.1029/2006JD007858

> Clavier CGJ, Boucher G (1992) The use of photosynthesis inhibitor (DCMU) for in situ metabolic and primary production studies on soft bottom benthos. Hydrobiologia 246:141-145

Falkowski PG (1997) Evolution of the nitrogen cycle and its influence on the biological sequestration of $\mathrm{CO}_{2}$ in the ocean. Nature 387:272-275

Farnelid H, Bentzon-Tilia M, Andersson AF, Bertilsson S and others (2013) Active nitrogen-fixing heterotrophic bacteria at and below the chemocline of the central Baltic Sea. ISME J 7:1413-1423
Fernandez C, Farias L, Ulloa O (2011) Nitrogen fixation in denitrified marine waters. PLoS ONE 6:e20539

Foster RA, Paytan A, Zehr JP (2009) Seasonality of $N_{2}$ fixation and nifH gene diversity in the Gulf of Aqaba (Red Sea). Limnol Oceanogr 54:219-233

Fuller NJ, West NJ, Marie D, Yallop M, Rivlin T, Post AF (2005) Dynamics of community structure and phosphate status of picocyanobacterial populations in the Gulf of Aqaba, Red Sea. Limnol Oceanogr 50:363-375

> Großkopf T, Mohr W, Baustian T, Schunck H and others (2012) Doubling of marine dinitrogen-fixation rates based on direct measurements. Nature 488:361-364

Gruber N (2008) The marine nitrogen cycle: overview of distributions and processes. In: Capone D, Bronk D, Mulholland M, Carpenter E (eds) Nitrogen in the marine environment. Elsevier, Amsterdam, p 1-50

> Halm H, Lam P, Ferdelman TG, Lavik G and others (2012) Heterotrophic organisms dominate nitrogen fixation in the South Pacific Gyre. ISME J 6:1238-1249

> Hamersley MR, Turk KA, Leinweber A, Gruber N, Zehr JP, Gunderson T, Capone DG (2011) Nitrogen fixation within the water column associated with two hypoxic basins in the Southern California Bight. Aquat Microb Ecol 63: 193-205

Holm-Hansen O, Lorenzen CJ, Holmes RW, Strickland JDH (1965) Fluorometric determination of chlorophyll. J Cons Perm Int Explor Mer 30:2-15

> Iluz D, Dishon G, Capuzzo E, Meeder E and others (2009) Short-term variability in primary productivity during a wind-driven diatom bloom in the Gulf of Eilat (Aqaba). Aquat Microb Ecol 56:205-215

> Karl D, Michaels A, Bergman B, Capone D and others (2002) Dinitrogen fixation in the world's oceans. Biogeochemistry $57: 47-98$

Knapp AN (2012) The sensitivity of marine $\mathrm{N}_{2}$ fixation to dissolved inorganic nitrogen. Front Microbiol 3:374

> Kress N, Herut B (2001) Spatial and seasonal evolution of dissolved oxygen and nutrients in the southern Levantine basin (Eastern Mediterranean Sea): chemical characterization of the water masses and inferences on the N:P ratios. Deep-Sea Res I 48:2347-2372

- Kustka AS, Sañudo-Wilhelmy S, Carpenter EJ, Capone DG, Raven JA (2003) A revised estimate of the iron efficiency of nitrogen fixation with special reference to the marine cyanobacterium Trichodesmium spp. (Cyanophyta). J Phycol 39:12-25

> Labiosa RG, Arrigo KR (2003) The interplay between upwelling and deep convective mixing in determining the seasonal phytoplankton dynamics in the Gulf of Aqaba: evidence from SEAWIFS and MODIS. Limnol Oceanogr 48:2355-2368

Lagaria A, Psarra S, Lefèvre F, Van Wambeke F and others (2010) The effects of nutrient additions on particulate and dissolved primary production in surface waters of three Mediterranean eddies. Biogeosci Discuss 7: 8919-8952

Lindell D, Post AF (1995) Ultraphytoplankton succession is triggered by deep winter mixing in the Gulf of Aqaba (Eilat), Red Sea. Limnol Oceanogr 40:1130-1141

Mackey KRM, Labiosa RG, Calhoun M, Street JH, Post AF, Paytan A (2007) Phosphorus availability, phytoplankton community dynamics, and taxon-specific phosphorus status in the Gulf of Aqaba, Red Sea. Limnol Oceanogr 52:873-885

Mackey KRM, Rivlin T, Grossman AR, Post AF, Paytan A 
(2009) Picophytoplankton responses to changing nutrient and light regimes during a bloom. Mar Biol 156: 1531-1546

Mague TH, Weare NM, Holmhans O (1974) Nitrogen fixation in the North Pacific Ocean. Mar Biol 24:109-119

Manasrah R, Zibdah M, Al-Ougaily F, Yusuf N, Al-Najjar T (2007) Seasonal changes of water properties and current in the northernmost Gulf of Aqaba, Red Sea. Ocean Sci J 42:103-116

Meeder E, Mackey KRM, Paytan A, Shaked Y and others (2012) Nitrite dynamics in the open ocean - clues from seasonal and diurnal variations. Mar Ecol Prog Ser 453: 11-26

Mohr W, Großkopf T, Wallace DWR, LaRoche J (2010) Methodological underestimation of oceanic nitrogen fixation rates. PLoS ONE 5:e12583

Montoya JP, Voss M, Kahler P, Capone DG (1996) A simple, high-precision, high-sensitivity tracer assay for $\mathrm{N}_{2}$ fixation. Appl Environ Microbiol 62:986-993

> Montoya JP, Holl CM, Zehr JP, Hansen A, Villareal TA, Capone DG (2004) High rates of $\mathrm{N}_{2}$ fixation by unicellular diazotrophs in the oligotrophic Pacific Ocean. Nature 430:1027-1032

Moore CM, Mills M, Arrigo KR, Berman-Frank I and others (2013) Processes and patterns of oceanic nutrient limitation. Nat Geosci 6:701-710

Mulholland MR, Bernhardt PW (2005) The effect of growth rate, phosphorus concentration, and temperature on $\mathrm{N}_{2}$ fixation, carbon fixation, and nitrogen release in continuous cultures of Trichodesmium IMS101. Limnol Oceanogr 50:839-849

Mulholland MR, Bernhardt PW, Heil CA, Bronk DA, O'Neil JM (2006) Nitrogen fixation and release of fixed nitrogen by Trichodesmium spp. in the Gulf of Mexico. Limnol Oceanogr 51:1762-1776

Mulholland MR, Bernhardt PW, Blanco-Garcia JL, Mannino A and others (2012) Rates of dinitrogen fixation and the abundance of diazotrophs in North American coastal waters between Cape Hatteras and Georges Bank. Limnol Oceanogr 57:1067-1083

> Paytan A, Mackey KRM, Chen Y, Lima ID and others (2009) Toxicity of atmospheric aerosols on marine phytoplankton. Proc Natl Acad Sci USA 106:4601-4605

Post AF, Dedej Z, Gottlieb R, Li H and others (2002) Spatial and temporal distribution of Trichodesmium spp. in the stratified Gulf of Aqaba, Red Sea. Mar Ecol Prog Ser 239: 241-250

> Postgate J (1998) The origins of the unit of nitrogen fixation at the University of Sussex. Notes Rec R Soc Lond 52: 355-362

Rahav E, Bar Zeev E, Ohayon S, Elifantz H and others (2013a) Dinitrogen fixation in aphotic oxygenated marine environments. Front Microbiol 4:227

Rahav E, Herut B, Stambler N, Bar-Zeev E, Mulholland MR, Berman-Frank I (2013b) Uncoupling between dinitrogen fixation and primary productivity in the Eastern Mediter-

Editorial responsibility: Graham Savidge,

Portaferry, UK ranean Sea. J Geophys Res Biogeosci 118:195-202

Rahav E, Herut B, Levi A, Mulholland MR, Berman-Frank I (2013c) Springtime contribution of dinitrogen fixation to primary production across the Mediterranean Sea. Ocean Sci 9:489-498

Raven JA (1988) The iron and molybdenum use efficiencies of plant growth with different energy, carbon and nitrogen sources. New Phytol 109:279-287

Redfield AC, Ketchum BH, Richards FA (1963) The influence of organisms on the composition of sea water. In: Hill MN (ed) The sea. Ideas and observations on progress in the study of the seas. Interscience Publishers, John Wiley \& Sons, New York, NY, p 26-77

Sañudo-Wilhelmy SA, Kustka AB, Gobler CJ, Hutchins DA and others (2001) Phosphorus limitation of nitrogen fixation by Trichodesmium in the central Atlantic Ocean. Nature 411:66-69

Sebastián M, Gasol JM (2013) Heterogeneity in the nutrient limitation of different bacterioplankton groups in the Eastern Mediterranean Sea. ISME J 7:1665-1668

Simon M, Azam F (1989) Protein content and protein synthesis rates of planktonic marine bacteria. Mar Ecol Prog Ser 51:201-213

Simon M, Cho BC, Azam F (1992) Significance of bacterial biomass in lakes and the ocean: comparison to phytoplankton biomass and biogeochemical implications. Mar Ecol Prog Ser 86:103-110

Smith DC, Azam F (1992) A simple, economical method for measuring bacterial protein synthesis rates in seawater using ${ }^{3} \mathrm{H}$-leucine. Mar Microb Food Webs 6:107-114

Sohm JA, Webb EA, Capone DG (2011) Emerging patterns of marine nitrogen fixation. Nat Rev Microbiol 9:499-508

Sommer U (2000) Scarcity of medium-sized phytoplankton in the northern Red Sea explained by strong bottom-up and weak top-down control. Mar Ecol Prog Ser 197: 19-25

> Thingstad TF, Krom MD, Mantoura RFC, Flaten GAF and others (2005) Nature of phosphorus limitation in the ultraoligotrophic Eastern Mediterranean. Science 309: 1068-1071

Weiss RF (1970) Solubility of nitrogen, oxygen and argon in water and seawater. Deep-Sea Res 17:721-735

- White AE, Prahl FG, Letelier RM, Popp BN (2007) Summer surface waters in the Gulf of California: prime habitat for biological $\mathrm{N}_{2}$ fixation. Global Biogeochem Cycles 21: GB2017, doi:10.1029/2006GB002779

> Wilson ST, Boettjer D, Church MJ, Karl DM (2012) Comparative assessment of nitrogen fixation methodologies, conducted in the oligotrophic North Pacific Ocean. Appl Environ Microbiol 78:6516-6523

Wolf-Vecht A, Paldor N, Brenner S (1992) Hydrographic indications of advection convection effects in the Gulf of Eilat. Deep-Sea Res A 39:1393-1401

Zehr JP, Kudela RM (2011) Nitrogen cycle of the open ocean: from genes to ecosystems. Annu Rev Mar Sci 3: $197-225$

Submitted: June 30, 2014; Accepted: December 1, 2014 Proofs received from author(s): February 9, 2015 